\title{
Osteoporosis in Rheumatoid Arthritis: A Molecular Biological Aspect of Connective Tissue Gene Activation
}

\author{
Shunichi Shiozawa and Yasuo Kuroki \\ Department of Medicine, 3rd Division, Kobe University \\ School of Medicine, Kobe 650
}

\begin{abstract}
Shiozawa, S. and Kuroki, Y. Osteoporosis in Rheumatoid Arthritis: A Molecular Biological Aspect of Connective Tissue Gene Activation. Tohoku J. Exp. Med., 1994, 173(1), 189-198— Osteoporosis, especially the juxtaarticular osteoporosis of involved joints, is a characteristic manifestation of rheumatoid arthritis (RA). Histomorphometric studies suggest the existence of increased bone turnover in RA: impaired bone formation and hightened osteoclastic bone resorption. Recent studies show that important mediators in the pathogenesis of RA such as prostaglandin E, interleukin 1 (IL1) or tumor necrosis factor (TNF) $\alpha$ also play important roles in bone remodelling. Prostaglandin $\mathrm{E}_{2}$ promotes maturation of osteoclasts from hematopoietic precursor cells. IL1 inhibits collagen synthesis in osteoblasts. IL1 enhances collagenase and stromelysin gene expression and stimulates osteoclastic bone resorption. TNF $\alpha$ inhibits bone collagen synthesis and causes osteoclastic bone resorption. $\mathrm{TNF} \alpha$, and possibly IL1, enhances collagenase and stromelysin gene expression by stimulating the AP-1 promotor sites of the genes. Constitutive expression of c-fos induces joint destruction without lymphocyte infiltration in antigen-induced arthritis in mice, and supports cell growth of human rheumatoid synovial cells, possibly acting on the AP-1 sites. Furthermore, constitutive c-fos expression decreases collagen synthesis in osteoblasts and increases the mediator secretion from osteoblasts thereby stimulating osteoclastic bone resorption. These findings suggest that signal transduction through AP-1 transcriptional regulation sties may play an important role in the pathogenesis of joint destruction and osteoporosis in RA.—c-fos; collagen; collagenase; osteoporosis; rheumatoid arthritis
\end{abstract}

We discuss here the pathogenesis of osteoporosis in rheumatoid arthritis (RA) by reviewing the recent developments in the cytokine action and gene expression in collagenous tissues.

Address for reprints: S. Shiozawa, Department of Medicine, 3rd Division, Kobe University School of Medicine, 7-5 Kusunokicho, Chuoku, Kobe 650, Japan.

Abbreviations: CRE, cAMP-responsive element; IL, interleukin; MMP, matrix metalloproteinase ${ }^{1}$; $\mathrm{PGE}$, prostaglandin $\mathrm{E}$; $\mathrm{PTH}$, parathormone; $\mathrm{RA}$, rheumatoid arthritis; TGF, transforming growth factor; TNF, tumor necrosis factor; TRE, TPA-responsive element.

${ }^{1}$ Classification of MMP according to Biochem. J. (Great Britain) 254, 731-741 (1988).

${ }^{2}$ Capital letter such as c-Fos indicates transcriptional factor derives from c-fos gene. 


\section{Osteoporosis in rheumatoid arthritis}

Juxtaarticular osteoporosis of involved joints is a characteristic early manifestation of RA. This appears very early in the disease course, sometimes within a few months after the onset of the disease (Sambrook et al. 1985b; Verstraeten and Dequeker 1986). Compared with juxtaarticular osteoporosis, the involvement of axial skeleton is relatively minor in degree (Compston et al. 1988). Bone histomorphometric study of the juxtaarticular bone obtained during joint surgery indicates hightened bone turnover in RA: impaired bone formation and increased osteoclastic bone resorption (Shimizu et al. 1985). Bone biopsy in the rib and iliac crest suggests impaired bone formation as a basis for generalized osteoporosis in RA (Ramser et al. 1966; Van Soesbergen et al. 1986; Compston et al. 1989; Krфger et al. 1991). However, the histological changes in the generalized osteoporosis of RA are usually minor and often statistically insignificant ( $\mathrm{Ng}$ et al. 1984). Histologic studies are usually carried out certain periods after the onset of RA and, therefore, may not correctly reflect the early changes of RA, however, these histopathological findings appear to be substantiated by the results of functional studies such as the increase of generalized ${ }^{99} \mathrm{Tc}^{\mathrm{m}}$ methylene diphosphonate retention (Rajapakse et al. 1983) or increased urinary excretion of deoxypyridinoline, a bone specific cross-link, in active RA (Seibel et al. 1989).

Metabolic changes such as the decrease of intestinal calcium absorption (Sambrook et al. 1985a) or serum 25-hydroxyvitamin $\mathrm{D}_{3}$ levels (Van Soesbergen et al. 1986; Pietschmann et al. 1989; Rico et al. 1990) and reduced PTH secretion in response to lowered calcium (af Ekenstam et al. 1990) exist in RA. There is a correlation between the initial increased levels of PTH and 1,25dihydroxyvitamin $D_{3}$ and subsequent bone loss in RA (Sambrook et al. 1990). However, these changes are often statistically insignificant in other studies ( $\mathrm{Ng}$ et al. 1984; Seibel et al. 1989; Joffe and Epstein 1991; Peel et al. 1991). Instead, the synovial inflammatory changes could play important roles in the pathogenesis of juxtaarticular osteoporosis in RA as exemplified by the effectiveness of antirheumatic drugs on rheumatoid osteoporosis (Seibel et al. 1989; Kalla et al. 1991).

\section{Mediators common to rheumatoid arthritis and bone remodelling}

Bone is a dynamic organ under continous remodelling, in which osteoclastic bone resorption is tightly coupled with osteoblastic bone formation with no net change in skeletal mass (Watrous and Andrews 1989). Osteoblast is characterised by the production of alkaline phosphatase, type 1 collagen and other extracellular matrix proteins including osteocalcin. Osteoclast is a multinucleated giant cell characterized by the expression of tartarate resistant acid phospatase and calcitonin receptor on the cell surface (Nicholson et al. 1986). In addition to parathyroid hormone and 1,25-dihydroxyvitamin $\mathrm{D}_{3}$, the maturation of osteoclasts from precursor cells is also supported by interleukin 3 (IL3) (Barton and Mayer 
1989), macrophage- colony stimulating factor (M-CSF) (Takahashi et al. 1991), prostaglandins (PGs) (Collins and Chambers 1992), ILl plus tumor necrosis factor (TNF) (Pfeilschifter et al. 1989), and possibly by ILl alone (Akatsu et al. 1991). Because mediators such as PGE, ILl and TNF $\alpha$ are the most important cytokines in the pathogenesis of RA (Shiozawa and Tokuhisa 1992), we discuss here the roles of these mediators in the pathogenesis of collagenous matrix degradation and bone resorption in $\mathrm{RA}$.

$P G E$. $\mathrm{PGE}_{2}$ promotes maturation of osteoclasts from hematopoietic precursor cells (Collins and Chambers 1992). The precursor cells must contact with osteoblasts or bone stromal cells to achieve maturation (Takahashi et al. 1988; Collins and Chambers 1992). Osteoblasts and bone stromal cells facilitate differentiation of osteoclasts by producing $\mathrm{PGE}_{2}$ (Collins and Chambers 1992). However, the production of PGs is not an essential component of the ability of osteoblast/stromal cell to support osteoclast formation (Collins and Chambers 1992). In contrast, $\mathrm{PGE}_{2}$ inhibits biological functions of mature osteoclasts, i.e., osteoclastic bone resorption (Chambers et al. 1985). $\mathrm{PGE}_{2}$ also stimulates collagen synthesis in osteoblasts (Hakeda et al. 1985). $\mathrm{PGE}_{2}$ inhibits $92 \mathrm{kDa}$ type IV collagenase/gelatinase (MMP-9) ${ }^{1}$ production from activated monocytes by increasing intracytoplasmic cAMP, whereas $\mathrm{PGE}_{2}$ does not affect basal production of this enzyme from non-activated monocytes (Corcoran et al. 1992). $\mathrm{PGE}_{1}$, but not $\mathrm{PGE}_{2}$ or $\mathrm{PGE}_{2 \alpha}$, inhibits phorbol ester-induced collagenase (types unkown) gene expression in rabbit synoviocytes and also in human fibroblasts by raising intracellular cAMP, thereby acting on the promotor region of the gene (Salvatori et al. 1992). However, the classical cAMP-responsive element (CRE) has not been identified in the promoter region of the gene (Angel et al. 1987a). Moreover, all of the CRE sites identified to date are associated with a stimilatory effect (Roesler et al. 1988). It thus appears that different mechanisms must be operating in the inhibition of collagenase gene expression by cAMP. The inhibitory effect of $\mathrm{PGE}_{1}$ on the collagenase gene expression in synoviocytes and fibroblasts (Salvatori et al. 1992) is in contrast with the stimulatory effect of $\mathrm{PGE}_{1}$ on the collagenase gene expression in osteosarcoma cells (Partridge et al. 1987; Delaisse et al. 1988).

IL1. IL1 stimulates bone resorption in vitro (Gowen et al. 1983). If osteoblasts are removed from the culture, osteoclastic bone resorption in response to ILl disappears (Thomson et al. 1986). ILl inhibits collagen synthesis in osteoblasts and hepatic cells (Calalis 1986; Harrison et al. 1990; ArmendarizBorunda et al. 1992). ILl elevates basal levels of collagense (MMP-9) mRNA (Wilhelm et al. 1989) and stromelysin (MMP-3) gene expression (Sirum-Connolly and Brinckerhoff 1991) and increases gene transcription (Dayer et al. 1984) and secretion of collagenase (types unknown) in rheumatoid synoviocytes by stimulating 5' TPA-responsive element (TRE) sequence (Lafyatis et al. 1990).

$T N F \alpha$. TNF at $10^{-7}$ to $10^{-9}$ inhibits bone collagen synthesis and causes 
osteoclastic bone resorption (Bertolini et al. 1986). The TNF $\alpha$ and $\mathrm{TNF} \beta$ genes are single copy genes located within the cluster of major histocompatibility complex (MHC) genes. They are each approximately 3 kilobase long, and each gene consists of 4 exons and 3 introns (Vilcek and Lee 1991). The organization of the $\mathrm{TNF} \alpha$ and $\mathrm{TNF} \beta$ genes and their coding regions, especially the 4 th exons coding for $80-89 \%$ of the major proteins, show a high degree of homology. However, the $5^{\prime}$ flanking regions of the two genes that contain most of the transcriptional regulation sites are dissimilar. Thus, although TNF $\alpha$ and TNF $\beta$ bind to the same receptor and show similar spectra of biological activities, the regulation of the expression of two genes is completely different.

TNF, mostly TNF $\alpha$, is involved in the activation or increase of cAMP, PGs, protein kinase $\mathrm{A}$, protein kinase $\mathrm{C}, \mathrm{NF}-\varkappa \mathrm{B}, \mathrm{c}-f o s, \mathrm{c}-j$ un, IL1, collagenase, stromelysin and others (Vilcek and Lee 1991). TNF $\alpha$ stimulates $\mathrm{G}$ protein signalling in osteoblastic cells (Yanaga et al. 1992). TNF $\alpha$ promotes continuous expression of c-jun gene and in this way stimulates collagenase gene transcription by acting on the AP-1 site of the gene (Brenner at el. 1989). TNF $\alpha$ inhibits type I collagen gene expression (Solis-Herruzo et al. 1988). The function of the $\mathrm{NF}-\varkappa \mathrm{B}$ sites on the $\mathrm{TNF} \alpha$ gene which also exist in the promotor regions of IL2, IL3, IL4, IL6, granulocyte macrophage colony stimulating factor (GM-CSF) and interferon $\gamma\left(\operatorname{IFN}_{\gamma}\right)$ is unclear at present (McCaffrey at al. 1992). Partial deletion of $\mathrm{NF}-\varkappa \mathrm{B}$ sites from the $\mathrm{TNF} \alpha$ promotor had little influence on the induction of the gene by microbial agents (Goldfeld et al. 1990). It is interesting, however, in relation to the pathogenesis of RA that an $\mathrm{NF}-\varkappa \mathrm{B}$ site is essentially required for the induction of endothelial leukocyte adhesion molecule 1 (ELAM-1) mRNA (Whelan at al. 1991).

\section{Collagen, cellagenase and stromelysin}

Collagen. Transcriptional factors, CCAAT binding factor (CBF), IF1 and IF2, bind to the three transcriptional regulation sites in the promotor regions of $\alpha 2(1)$ and $\alpha 1(1)$ collagen genes (de Crombrugghe et al. 1991). CBF acts as a transcriptional activator and IF1 and IF2 act as inhibitors of the $\alpha 1$ (1) collagen promotor (Karsenty and de Crombrugghe 1990). Procollagen DNA contains the AP-1 sites in the upstream promotor position (Lichtler et al. 1989). Phorbol ester up-regulates c-fos/c-jun expression and also down-regulates $\alpha(1)$ collagen gene expression (Sassone-Corsi et al. 1989; Harrison et al. 1990). Constitutive expression of c-fos in transfected MC3T3-E1 osteoblastic cells inhibits gene expression and biosynthesis of $\alpha 1(1)$ collagen (Kuroki et al. 1992)

Collagenase. In addition to collagenase (MMP-1) and collagenase/ stromelysin (MMP-9), stromelysin (MMP-3) has also been identified in rheumatoid synovial cells (Okada et al. 1986; 1988). The AP-1 site is present in the promotor regions of collagenase (MMP-1 and MMP-9), stromelysin (MMP-3) and several other genes (Angel et al. 1987a, b; Gutman and Wasylyk 1990; Sirum-Connolly 
and Brinckerhoff 1991), and c-fos indeed up-regulates collagenase gene expresssion (Sch $\phi$ nthal et al. 1988).

Stromelysin. Stromelysin (MMP-3) contains the AP-1 site in its promoter region (Sirum-Connolly and Brinckerhoff 1991). The stromelysin promoter responds efficiently to c-Ets and c-Jun/c-Fos ${ }^{2}$ complex (oncogene products) independently (Wasylyk et al. 1991). On the other hand, IL1 up-regulates stromelysin gene transcription through protein kinase $\mathrm{C}$ activation, and downregulates stromelysin transcription through protein kinase $\mathrm{A}$ activation (Case et al. 1990). Although cAMP and epidermal growth factor (EGF), but not platelet derived growth factor (PDGF), fibroblast growth factor (FGF) nor transforming growth factor $\beta$ (TGF $\beta$ ), induce stromelysin gene expression, the CRE site is again not identified in the promotor region of stromelysin (Matrisian et al. 1986).

\section{Rheumatoid synovial cell growth and $c$-fos}

Rheumatoid pannus, a vascular and flbrous granulation tissue that invades cartilage and bone, is composed of synovial mesenchymal cells (Shiozawa and Shiozawa 1988). Pannus first covers articular surface of cartilage as morphologically quiescent fibroblast-like cells and subsequently starts invasion into collagenous matrix as macrophage-like cells befere blood vessel infiltration (Shiozawa et al. 1983). These infiltrating synovial cells are regarded as tumor-like in nature by European investigators (Fassbender 1983), and this type of transformed-appearing synovial cell growth is also seen in MRL/I mice, an animal model for RA (Tanaka et al. 1988). Thus, tumor-like growth characteristic is an attribute of rheumatoid synovial cells.

This tumor-like growth can be adorned to synovial cells experimentally augmenting c-fos oncogene expression. By inducing antigen-induced arthritis in $\mathrm{H}-2$-c-fos transgenic mice that constitutively express c-fos, the joint destruction without local lymphocyte infiltration is experimentally produced: the only cells invading the cartilage and bone are c-fos-positive mesenchymal synovial cells reminiscent of rheumatoid pannus (Shiozawa et al. 1992). Constitutive expression of c-fos in human rheumatoid synovial cells facilitates morphological transformation of dendritic synovial cells into fibroblastic cells, thereby augmenting the growth of synovial cells (Kuroki et al. 1993).

\section{Bone resorption and $c$-fos gene}

A transfection study shows that constitutive expression of c-fos gene inhibits gene expression and biosynthesis of $\alpha 1(\mathrm{I})$ collagen in MC3T3-E1 osteoblastic cells (Kuroki et al. 1992), possibly by acting on the AP-1 site in the promoter region of procollagen DNA (Lichtler et al. 1989). Culture supernatant of c-fos-expressing MC3T3-E1 cells promotes maturation of osteoclasts from precursor cells (Kuroki et al. 1994). The culture supernatant also augments osteoclastic bone resorption as revealed by the Chamber's pit formation technique on a devitalized bone slice 
(Kuroki et al. 1994).

\section{Regulation at $A P-1$ site and rheumatoid arthritis}

The AP-1 site is important for the transcriptional control of collagen and collagenase/stromelysin genes by TNF $\alpha$ and IL1. TNF $\alpha$ stimulates collagenase gene transcription by raising c-Jun thereby acting on the AP-1 sites of the gene (Brenner et al. 1989). The stimulation of stromelysin gene transcription by IL1 is also mediated by the AP-1 and additional upstream regulatory sites in the promotor region of the genes (Sirum-Connolly and Brinckerhoff 1991). The promotor region of stromelysin gene contains only one AP-1 site which is not highly responsive to ILl: both the AP-1 site and additional promoter sites are required for the maximal response. This type of synergistic or additive cooperation between the AP-1 site and additional transcriptional regulation sites is also seen in the transcriptional control of collagenase gene (Gutman and Wasylyk 1990). Furthermore, it is interesting that TGF- $\beta$ inhibits transin/stromelysin gene expression by increasing the transcriptional factor containing c-Fos (Kerr et al. 1990). This is an example that c-fos acts not always stimulatory but also regulatory in the transcriptional control of gene expression.

It is by no means certain whether the c-fos activation is absolutely required for the signal transduction by TNF $\alpha$ or IL1 or not, however, evidence obtained so far indicates that hightened stimulation of AP-1 sites is clearly pathological as exemplified by a series of c-fos transgenic studies and produces a pathological feature similar to human RA.

\section{Acknowledgments}

This review article is dedicated to our teacher Prof. Masahisa Kyogoku on his retirement, with many thanks for his long-lasting and warm teachings.

\section{References}

1) af Ekenstam, E., Benson, L., Hallgren, R., Wide, L. \& Ljunghall, S. (1990) Impaired secretion of parathyroid hormone in patients with rheumatoid arthritis: Relationship to inflammatory activity. Clin. Endocrinol., 32, 323-328.

2) Akatsu, T., Takahashi, N., Udagawa, N., Imamura, K., Yamaguchi, A., Sato, K., Nagata, N. \& Suda, T. (1991) The role of prostaglandins in interleukin-1-induced bone resorption in mice in vitro. J. Bone Mineral Res., 6, 183-190.

3) Angel, P., Baumann, I., Stein, B., Delius, H., Rahmsdorf, H.J. \& Herrlich, P. (1987ẩ) 12-o-tetradecanoyl-phorbol-13-acetate induction of the human collagenase gene is mediated by an inducible enhancer element located in the $5^{\prime}$-flanking region. Mol. Cell. Biol., 7, 2256-2266.

4) Angel, P., Imagawa, M., Chiu, R., Stein, B., Imbra, R.J., Rahmsdorf, H.J., Jonat, C., Herrlich, P. \& Karin, M. (1987b) Phorbol ester inducible genes contain a common cis element recognized by a TPA-modulated trans-acting factor. Cell, 49, 729-739.

5) Armendariz-Borunda, J., Katayama, K. \& Seyer, J.M. (1992) Transcriptional mechanisms of type I collagen gene expression are differentially regulated by interleukin- $1 \beta$, tumor necrosis factor $\alpha$, and transforming growth factor $\beta$ in lto cells. J. Biol. Chem., 
267, 14316-21.

6) Barton, B.E. \& Meyer, R. (1989) IL-3 induces differentiation of bone marrow precursor cells to osteoclast-like cells. J. Immunol., 143, 3211-3216.

7) Bertolini, D.R., Nedwin, G.E., Brigman, T.S., Smith, D.D. \& Mundy, G.R. (1986) Stimulation of bone resorption and inhibition of bone formation in vitro by human tumor necrosis factors. Nature, 319, 516-518.

8) Brenner, D.A., O'Hara, M., Angel, P., Chojkier, M. \& Karin, M. (1989) Prolonged activation of jun and cllagenase genes by tumour necrosis factor- $\alpha$. Nature, 337, 661-663.

9) Calalis, E. (1986) Interleukin-1 has independent effects on deoxyribonucleic acid and collagen synthesis in clutures of rat calvariae. Endocrinology, 118, 74-81.

10) Case, J.P., Lafyatis, R., Kumkumian, G.K., Remmers, E.F. \& Wilder, R.L. (1990) IL-1 regulation of transin/stromelysin transcription in rheumatoid synovial fibroblasts appears to involve two antagonistic transduction pathways, an inhibitory, prostaglandin-dependent pathway mediated by cAMP, and a stimulatory, protein kinase C-dependent pathway. J. Immunol., 145, 3755-3761.

11) Chambers, T.J., McSheehy, P.M.J., Thomson, B.M. \& Fuller, K. (1985) The effect of calcium-regulating hormones and prostaglandins on bone resorption by osteoclasts disaggregated from neonatal rabbit bones. Endocrinology, 116, 234-239.

12) Collins, D.A. \& Chambers, T.J. (1992) Prostagladin E2 promotes osteoclast formation in murine hematopoietic cultures through an action on hematopoietic cells. $J$. Boen Mineral Res., 7, 555-561.

13) Compston, J.E., Crawley, E.O., Evans, C. \& O'Sullivan, M.M. (1988) Spinal trabecular bone mineral content in patients with non-steroid treated rheumatoid arthritis. Ann. Rhem. Dis., 47, 660-664.

14) Compston, J.E., Vedi, S., Mellish, R.W.E., Croucher, P. \& O'Sullivan, M.M. (1989) Reduced bone formation in non-steroid treated patients with rheumatoid arthritis. Ann. Rheum. Dis., 48, 483-487.

15) Corcoran, M.L., Stetler-Stevenson, W.G., Brown, P.D. \& Wahl, L.M. (1992) Interleukin 4 inhibition of prostaglandin $\mathrm{E}_{2}$ synthesis blocks interstitial collagenase and 92-kDa type IV collagenase/gelatinase production by human monocytes. J. Biol. Chem., 267, 515-519.

16) Dayer, J-M., Zavadil-Grob, C., Ucla, C. \& Mach, B. (1984) Induction of human interleukin-1 mRNA measured by collagenase-and prostaglandin $\mathrm{E}_{2}$-stimulating activity in rheumatoid synovial cells. Eur. J. Immunol., 14, 898-901.

17) de Crombrugghe, B., Vuorio, T., Karsenty, G., Maity, S., Rutheshouser, E.C. \& Goldberg, H. (1991) Transcriptional control mechanisms for the expression of type I collagen genes. Ann. Rheum. Dis., 50, 872-876.

18) Delaisse, J.M., Eeckhout, Y. \& Vaes, G. (1988) Bone resorbing agents affect the production and distribution of procollagenase as well as the activity of collagenase in bone tissue. Endocrinology, 123, 264-276.

19) Fassbender, H-G. (1983) Histmmorphological basis of articular cartilage destruction in rheumatoid arthritis. Coll. Rel. Res., 3,141-155.

20) Goldfeld, A.E., Doyle, C. \& Maniatis, T. (1990) Human tumor necrosis factor $\alpha$ gene regulated by virus and lipopolysaccharide. Proc. Natl. Acad. Sci. USA, 87, 97699773.

21) Gowen, M., Wood, D.D., Ihrie, E.J., McGuire, M.K.B. \& Russell. R.G.G. (1983) An interleukin-1 like factor stimulates bone resorption in vitro. Nature, 306, 378-380.

22) Gutman, A. \& Wasylyk, B. (1990) The collagenase gene promoter contains a TPA and oncogene-responsive unit encompassing the PEA3 and AP-1 binding sites. EMBO J., 9, 2241-2246.

23) Hakeda, Y., Nakatani, Y., Kurihara, N., Ikeda, E., Maeda, N. \& Kumegawa, M. (1985) Prostaglandin $\mathrm{E}_{2}$ stimulates collagen and non-collagen protein synthesis and prolyl 
hydroxylase activity in osteoblastic clone MC3T3-E1 cells. Biochem. Biophys. Res. Commun., 126, 340-345.

24) Harrison, J.R., Vargas, S.J., Petersen, D.N., Lorenzo, J.A. \& Kream, B.E. (1990) Interleukin-1 alpha and phorbol ester inhibit collagen synthesis in osteoblastic MC3T3-E1 cells by a transcriptional mechanism. Mol. Endocrinol., 4, 184-190.

25) Joffe, I. \& Epstein, S. (1991) Osteoporosis associated with rheumatoid arthritis: Pathogenesis and management. Sem. Arthritis Rheum., 20, 256-272.

26) Kalla, A.A., Meyers, O.L., Chalton, D., Heath, S., Brown, G.M.M., Smith, P.R. \& Burger, M.C. (1991) Increased metacarpal bone mass following 18 months of slowacting antirheumatic drugs for rheumatoid arthritis. Br. J. Rheumatol., 30, 91-100.

27) Karsenty, G. \& de Crombrugghe, B. (1990) Two different negative and one positive regulatory factors interact with a short promoter segment of the $\alpha 1(\mathrm{I})$ collagen gene. J. Biol. Chem., 265, 9934-9942.

28) Kerr, L.D., Miller, D.B. \& Matrisian, L.M. (1990) TGF- $\beta 1$ inhibition of transin/ stromelysin gene expression is mediated through a Fos binding sequence. Cell, 61, 267-278.

29) Krøger, H., Arnala, I. \& Alhava, E.M. (1991) Bone remodeling in osteoporosis associated with rheumatoid arthritis. Calcif. Tissue Int., Suppl. 49, S90.

30) Kuroki, Y., Shiozawa, S., Sugimoto, T. \& Fujita, T. (1992) Constitutive expression of c-fos gene inhibits type 1 collagen synthesis in transfected osteoblasts. Biochem. Biophys. Res. Commun., 182, 1389-1394.

31) Kuroki, Y., Shiozawa, S., Yoshihara, R. \& Hotta, H. (1993) The contribution of humal c-fos DNA to cultured synovial cells: A transfection study. J. Rheumatol., 20, $422-428$.

32) Kuroki, K., Shiozawa, S., Sugimoto, T., Kanatani, M., Kaji, H., Miyauchi, H. \& Chihara, K. (1994) Constitutive c-fos expression in osteoflastic MC3T3-E1 cells stimulates osteoclast maturation and osteoclastic bone resorption. Clin. exp. Immunol., 95, 536-539.

33) Lafyatis, R., Kim, S-J., Angel, P., Roberts, A.B., Sporn, M.B., Karin, M. \& Wilder, R.L. (1990) Interleukin-1 stimulates and all-trans-retinoic acid inhibits collagenase gene expression through its 5' activator protein-1-binding site. Mol. Endocrinol., 4, 973-980.

34) Lịchtler, A., Stover, M.L., Angilly, J., Kream, B. \& Rowe, D.W. (1989) Isolation and characterization of the rat $\alpha 1$ (I) collagen promoter. J. Bil. Chem., 264, 3072-3077.

35) Matrisian, L.M., Leroy, P., Ruhlmann, C., Gesnel, M-C. \& Breathnach, R. (1986) Isolation of the oncogene and epidermal growth factor-induced transin gene: Complex control in rat fibroblasts. Mol. Cell. Biol., 6, 1679-1686.

36) McCaffrey, P. G., Jain, J., Jamieson, C., Sen R. \& Rao, A. (1992) A T cell nuclear factor resembling NF-AT binds to an NF- $\varkappa \mathrm{B}$ site and to the conserved lymphokine promoter sequence "cytokine-1". J. Biol. Chem., 267, 1864-1871.

37) Ng, K.C., Revell, P.A., Beer, M., Boucher, B.J., Cohen, R.D. \& Currey, H.L.F. (1984) Incidence of metabolic bone disease in rheumatoid arthritis and osteoarthritis. Ann. Rheum. Dis., 43, 370-377.

38) Nicholson, G.C., Moseley, J.M., Sexton, P.M., Mendelsohn, F.A.O. \& Martin, T.J. (1986) Abundant calcitonin receptors in iolated rat osteoclasts. J. Clin. Invest., 78, $355-360$.

39) Okada, Y., Nagase, H. \& Harris, E.D., Jr. (1986) A metalloproteinase from human rheumatoid synovial fibroblasts that digests connective tissue matrix components. $J$. Biol. chem., 261, 14245-14255.

40) Okada, Y., Harris, E.D., Jr. \& Nagase, H. (1988) The precursor of a metalloendopeptidase from human rheumatoid synovial fibroblasts. Biochem. J. (Great Britain) 254, 731-741.

41) Partridge, N.C., Jeffrey, J.J., Ehlich, L.S., Teitelbaum, S.L., Fliszar, C., Welgus, H.G. 
\& Kahn, A.J. (1987) Hormonal regulation of the production of collagenase and a collagenase inhibitor activity by rat osteogenic sarcoma cells. Endocrinology, 120, 1956-1962.

42) Peel, N.F.A., Eastell, R. \& Russell. R.G.G. (1991) Osteoporosis in rheumatoid arthritis - the laboratory perspective. Br. J. Rheumatol., 30, 84-85.

43) Pfeilschifter, J., Chenu, C., Bird, A., Mundy, G.R. \& Roodman, G.D. (1989) Interleukin-1 and tumor necrosis factor stimulate the formation of human osteoclastlike cells in vitro. J. Bone Mineral Res., 4, 113-118.

44) Pietschmann, P., Machold, K.P., Wolosczuk, W. \& Smolen, J.S. (1989) Serum osteocalcin concentrations in patients with rheumatoid arthritis. Ann. Rheum. Dis., 48, 654-657.

45) Rajapakse, C., Thompson R., Grennan, D.M., Winston, B.M., Patel, P., Nuttall, P.M., Murphy, J. \& Weiss, J.B. (1983) Increased bone metabolism in rheumatoid arthritis as measured by the whole-body retention of ${ }^{99} \mathrm{Tc}^{\mathrm{m}}$ methylene diphosphonate. Ann. Rheum. Dis., 42, 138-141.

46) Ramser, J.R., Duncan, H., Landeros, O., Epker, B. \& Frost, H.M. (1966) Measurements of bone dynamics in seven patieunts with salicylate-treated rheumatoid arthritis. Arthritis Rheum., 9, 424-430.

47) Rico, H., Hernandez, E.R., Gomez-Castresana, F., Yague, M., Cabranes, J.A. \& Valor, R. (1990) Osteopenia in rheumatoid arthritis: A biochemical, hormonal and histomorphomentic study. Clin. Rheumatol., 9, 63-68.

48) Roesler, W.J., Vandenbark, G.R. \& Hanson, R.W. (1988) Cyclic AMP and the induction of eukaryotic gene transcription. J. Biol. Chem., 263, 9063-9066.

49) Salvatori, R., Guidon, P.T., Jr., Rapuano, B.E. \& Bockman, R.S. (1992) Prostaglandin $\mathrm{E}_{1}$ inhibits collagenase gene expression in rabbit synoviocytes and human fibroblasts. Endocrinology, 131, 21-28.

50) Sambrook, P.N., Abeyasekera, G., Ansell, B.M., Foster, S., Gumpel, J.M., Hill, P.A., Reeve, J. \& Stevenson, J.C. (1985a) Calcium absorption in rheumatoid arthritis. Ann. Rheum. Dis., 44, 585-588.

51) Sambrook, P.N., Ansell, B.M., Foster, S., Gumpel, J.M., Hesp, R. \& Reeve, J. (1985b) Bone turnover in early rheumatoid arthritis. 2. Longitudinal bone density studies. Ann. Rheum. Dis., 44, 580-584.

52) Sambrook, P.N. Shawe, D., Hesp, R., Zanelli, J.M., Mitchell, R., Katz, D., Gumpel, J.M., Ansell, C.M. \& Reeve, J. (1990) Rapid periarticular bone loss in rheumatoid arthritis. Possible promotion by normal circulating concentrations of parathyroid hormone or calcitriol (1, 25-dihydroxyvitamin $\mathrm{D}_{3}$ ). Arthritis Rheum., 33, 615-622.

53) Sassone-Corsi, P., Der, C.J. \& Verma, I.M. (1989) ras-induced neuronal differentiation of PC12 cells: Possible involvement of fos and jun. Mol. Cell. Biol., 9, 3174-3183.

54) Schфnthal, A., Herrlich, P., Rahmsdorf, H.J., Ponta, H. (1988) Requirement for fos gene expression in the transcriptional activation of collagenase by other oncogens and phorbol esters. Cell, 54, 325-334.

55) Seibel, M.J., Duncan, A. \& Robins, S.P. (1989) Urinary hydroxypyridinium crosslinks provide indices of cartilage and bone involvement in arthritic diseases. $J$. Rheumatol., 16, 964-70.

56) Shimizu, S., Shiozawa, S., Shiozawa, K., Imura, S. \& Fujita, T. (1985) Quantitative histologic studies on the pathogenesis of periarticular osteoporosis in rhuumatoid arthritis. Arthritis Rheum., 28, 25-31.

57) Shiozawa, S. \& Shiozawa, K. (1988) A review of the histopathological evidence on the pathogenesis of cartilage destruction in rheumatoid arthritis. Scand. $J$. Rheumatol., Suppl. 74, 65-72.

58) Shiozawa, S. \& Tokuhisa, T. (1992) Contribution of synovial mesenchymal cells to the pathogenesis of rheumatoid arthritis. Sem. Arthritis Rheum., 21, 267-273. 
59) Shiozawa, S., Shiozawa, K. \& Fujita, T. (1983) Morphologic observations in the early phase of the cartilage-pannus junction. Light and electron microscopic studies of active cellular pannus. Arthritis Rheum., 26, 472-478.

60) Shiozawa, S., Tanaka, Y., Fujita, T. \& Tokuhisa, T. (1992) Destructive arthritis without lymphocyte infiltration in H2-c-fos transgenic mice. J. Immunol., 148, 31003104.

61) Sirum-Connolly, K. \& Brinckerhoff, C. (1991) Interleukin-1 or phorbol induction of the stromelysin promoter requires an element that cooperates with AP-1. Nucleic Acids Res., 19, 335-341.

62) Solis-Herruzo, J.A., Brenner, D.A. \& Chojkier, M. (1988) Tumor necrosis factor $\alpha$ inhibits collagen gene transcription and collagen synthesis in cultured human fibroblasts. J. Biol. Chem., 263, 5841-5845.

63) Takahashi, N., Akatsu, T., Udagawa, N., Sasaki, T., Yamaguchi, A., Moseley, J.M., Martin, T.J. \& Suda, T. (1988) Osteoblastic cells are involved in osteoclast formation. Endocrinolgy, 123, 2600-2602.

64) Takahashi, N., Udagawa, N., Akatsu, T., Tanaka, H., Shionome, M. \& Suda, T. (1991) The role of colony stimulating factors in osteoclast development: Osteoclast progenitors proliferate in response to macroghage colony stimulating factor. J. Bone Mineral Res., 6, 977-985.

65) Tanaka, A., O'Sullivan, F.X., Koopmal, W.J. \& Gay, S. (1988) Etiopathogenesis of the rheumatoid arthritis-like disease in MRL/l mice. II. Ultrastructural basis of joint destruction. J. Rheumatol., 15, 10-16.

66) Thomson, B.M., Saklatvala, J. \& Chambers, T.J. (1986) Osteoblasts mediate interleukin 1 stimulation of bone resosption by rat osteoclasts. J. Exp. Med., 164, 104112.

67) Van Soesbergen, R.M., Lips, P., Van Den Ende, A. \& Van Der Korst, J.K. (1986) Bone metabolism in rheumatoid arthritis compared with postmenopausal osteoporosis. Ann. Rheum. Dis., 45, 149-55.

68) Verstraeten, A. \& Dequeker, J. (1986) Vertebral and peripheral bone mineral content and fracture incidence in postmenopausal patients with rheumatoid arthritis: effect of low dose corticosteroids. Ann. Rheum. Dis., 45, 852-857.

69) Vilcek, J. \& Lee, T.H. (1991) Tumor necrosis factor. New insights into the molecular mechanisms of its multiple actions. J. Biol. Chem., 266, 7313-7316.

70) Wasylyk, C., Gutman, A., Nicholson, R. \& Wasylsk, B. (1991) The c-Ets oncoprotein activates the stromelysin promoter through the same elements as several non-nuclear oncoproteins. EMBO J. 10, 1127-1134.

71) Watrous, D.A. \& Andrews, B.S. (1989) The metabolism and immunology of bone. Sem. Arthritis Rheum., 19, 45-65.

72) Whelan, J, Ghersa, P., van Huijsduijnen, R.H., Gray, J., Chandra, G., Talabot, F. \& Delamarter, J.F. (1991) An NFkB-like factor is essential but not sufficient for cytokine induction of endothelial leukocyte adhesion molecule 1 (ELAM-1) gene transcription. Ncleic Acids Res., 19, 2645-2653.

73) Wilhelm, S.M., Collier, I.E., Marmer, B.L., Eisen, A.Z., Grant, G.A. \& Goldberg, G.I. (1989) SV-40-transformed human ludg fibroblasts secrete a 92-kDa type IV collagenase which is identical to that secreted by normal human macrophages. J. Biol. Chem., 264, 17213-17221.

74) Yanaga, F., Abe, M., Koga, T. \& Hirata, M. (1992) Signal transduction by tumor necrosis factor $\alpha$ is mediated through a guanine nucleotide-binding protein in osteoblast-like cell line, MC3T3-E1. J. Biol. Chem., 267, 5114-5121. 